\title{
English Teachers' Professional Competence in Comprehending Factual Text in Padang Pariaman Regency
}

\author{
Triani Oktarina ${ }^{1}$ and Hermawati Syarif ${ }^{2}$ \\ ${ }^{1}$ Universitas Negeri Padang, Padang, Indonesia, $ه($ (email),trianioktarina87@gmail.com. \\ ${ }^{2}$ Universitas Negeri Padang, Padang, Indonesia, $\triangle($ (email), hermawati_sy@fbs.unp.ac.id.
}

\begin{abstract}
English teachers' professional competence is interesting to be discussed since it is about the ability of English teachers in mastering learning materials deeply in order to guide the students to achieve competency standard. This is a descriptive research which aims to describe the professional competence of junior high school English teachers in Padang Pariaman regency in comprehending factual texts. In addition this research also explores the problems of English teachers of junior high school in comprehending factual text and their strategies to solve the problems. Furthermore, this research is addressed to twenty English teachers of junior high school in Padang Pariaman regency. There are two instruments are used in data collection processes, such as test and questionnaire. Based on the data, it is found out that there are so many English teachers failed in the test and most of English teachers of junior high school faced some non-linguistics problem in comprehending factual text.
\end{abstract}

Keywords: Professional competence, English teachers of junior high school, comprehending factual text.

\section{INTRODUCTION}

Government believes that Indonesia will have a better education if the teachers have good competencies. Based on the regulation no. 14 year 2005 and also no. 19 year 2005, there are four basic competencies every teacher should have, namely pedagogical, professional, social and personal. It is also supported by Mulyasa (2009) who states that teachers should have pedagogical, professional, social and personal competence to create a good learning process for students since each competence deals with different field. Those competencies are believed have covered every ability and skill of a good teacher that could shape education of Indonesia.

One of teachers' competencies which is a very interesting topic debated these days is professional competence. Based on observation in some junior high schools, there were still so many English teachers who were not only still confused about some materials but also forget few basic things about the material. In addition, based on the data of UKG (Uji Kompetensi Guru) in 2015 only $44.5 \%$ of teachers could achieve the standard of UKG. This phenomena also happened in Sumatera Barat, the average score of teachers in Sumatera Barat was only 55 while the standard score to pass the test is 70 . For details, based on the data from Pusat Pengembangan dan Pemberdayaan Pendidik dan Tenaga Kependidikan (PPPPTK) it was found there were more than 60 percent of English teachers failed in UKG (Uji Kompetensi Guru) 2017 which was conducted in Padang Pariaman regency. It was shown by the score of the English teachers who mostly only got 50-65 while the minimum standard of test was 70

According to Regulation No. 14 year 2005 professional competence has five sub competencies. One of sub competencies refers to mastering learning material which is explained more in Government Regulation No.19 year 2005. Knowledge of English teachers about the learning material is one of the aspects which could reflect their professional competence. The greater knowledge they have related to the subject they are teaching, the better professional competence they have. English teachers need to have a great knowledge related to the subject matter in order to carry out teaching and learning process well. In other words, English teachers' knowledge of learning material is an essential thing to be mastered. However, the result of UKG has shown that there are many English teachers of junior high school in Padang Pariaman faced some difficulties in understanding the materials they are going to teach in the class. For junior high school the materials are mostly about texts. In other words, there are many English teachers in junior high school who still have problem in comprehending texts.

There are some researchers having conducted the researches about professional competence, but previous researchers only discussed about English teachers professional competence related to the ability of them in large scope. Anugerahwati and Saukah (2010) analyzed professional competence of English teachers in Indonesia 
to find out a profile exemplary of English teachers. Their findings talked about how pedagogical, professional, social, and personal competence supported English teachers to be the professional one. They also suggested English teachers should understand more about competencies to improve the education in Indonesia. While Atmaca (2017) reported a research about perception of English teachers' professional competence in Turkey. However there were many criticism and suggestion towards English teachers there related to their knowledge about English subject and other competencies to support their professionalism.

It can be seen there are many previous reseraches talked about professional competence of teachers. But, the researcher has not found yet the research which talk about English teachers' professional competence that is compatible with professional competence explained by goverment in Regulation No.14 year 2005. In addition, unlike the previous researchers who analyzed professional competence of English teachers in large scope, in this research the researcher will only focus on English teachers' professional competence related to their ability in comprehending texts. The researcher believes that it is necessary to analyze the ability of English teachers in comprehending texts since it is one of the ways to measure the knowledge of teachers related to the materials they will deliver in class.

Text is chosen in this research because most of the materials for English subject in junior high school are about text. Besides, text is also the material that is tested mostly in UKG (Uji Kompetensi Guru) for professional competence category. Since the scope of text is too broad, the researcher only discussed the professional competence of English teachers in comprehending factual texts. In addition, this research also described the problems are faced by English teachers in comprehending factual text and the strategies they do to solve their problems in comprehending factual text.

The problems in comprehending texts can be various. Shehu (2015) reports that most of readers have problems in recalling the information they just read, differentiating text type, background of knowledge, tenses, and unfamiliar vocabulary. In addition, Raisha (2017) categorizes the common problems in comprehending text into linguistic problems and non linguistic problems. Puspita (2017) also stated that most of readers have problems in unfamiliar words in the text, their background knowledge related to the text, the concept of the text, and the complex syntax is used in the text. she believes these are the main problems of readers in comprehending texts.

To overcome these problems, some strategies have been suggested by experts. One of them is by Mohktary and sheory (2002), they proposed three main strategies to solve the problems which are global reading strategies, problem solving strategies, support reading strategies. Furthermore, Wuthisingchai (2011) claims there are some appropriate strategies that can be applied to solve problems in comprehending text, such as anticipating content, recognizing text structure, integrating information, questioning information in the text, interpreting the text, and using general knowledge and associations. While Shehu (2015) reports that most of readers have problems in recalling the information they just read, differentiating text type, background of knowledge, tenses, and unfamiliar vocabulary.

\section{METHOD}

This is a descriptive research which aims to describe the professional competence of English teachers in comprehending factual text in Padang Pariaman regency. According to Gay (2000), descriptive study is used to get information about the preference, attitudes, and practices of people in order to answer the questions of current issues. Descriptive research is chosen since this type of research is appropriate to be used for finding and describing the data without testing any hypotheses.

The population of this research are English teachers of junior high school in Padang Pariaman regency who are joining MGMP (Musyawarah Guru Mata Pelajaran). There are 199 English teachers who are joining MGMP from 93 junior high schools in Padang Pariaman regency. While the sample for this research are 20 English teachers of junior high school who were chosen by using convenience sampling.

This research uses some instruments as tools to collect the data. The instruments are test and questionnaires. By using a test as an instrument, it is expected to get a concrete data to describe professional competence of English teachers in comprehending texts. Moreover, questionnaire is needed to get the data related to the problems of English teachers in comprehending factual texts and the strategies they do to solve the problems.

Test is chosen as an instrument in this research since it is an appropriate tool to measure the ability of English teachers of Junior high school in Padang Pariaman regency in terms of comprehending factual texts. Since there are so many factual texts for English subject, the researcher chose the factual texts for the question items based on the texts which are tested in UKG for junior high school English teachers. It will be tested in the form of higher level questions to measure the professional competence of English teachers in comprehending factual texts. The texts are annoucement, advertisement, news item, descriptive, discussion, and hortatory exposition.

For the test, the researcher adapted the indicators from UKG year 2017 for English teachers of junior high school. The test consists of 50 questions which need to be answered within 60 minutes. The indicators of questions items can be seen in the table 1 .

The second instrument in this research is questionnaire. The questionnaire is used to get the data related to the problem are faced by English teachers of junior high school in comprehending factual texts and their strategies to solve the problems. The indicators for problems in comprehending texts are adapted from the theories delivered by Shehu (2015), Puspita (2017), and Raisha (2017), and While the indicators for strategies solving the problems are adapted from Mohktary and 
sheory (2002), Wuthisingchai (2011), and Shehu (2015). The questonnaire consisted of 37 items which divided into two parts with 4-point likert scale.

Table 1. Indicators of Comprehending Factual Texts Test

\begin{tabular}{ll}
\hline Indicators & Type of Text \\
\hline $\begin{array}{l}\text { Identifying general } \\
\text { description of the text. }\end{array}$ & $\begin{array}{l}\text { Descriptive, } \\
\text { exposition,discussion, } \\
\text { announcement, news item. }\end{array}$ \\
\hline $\begin{array}{l}\text { Determining implicit } \\
\text { information of the text. }\end{array}$ & Announcement, discussion. \\
\hline $\begin{array}{l}\text { Determining explicit } \\
\text { information of the text. }\end{array}$ & $\begin{array}{l}\text { Descriptive, hortatory exposition, } \\
\text { discussion, announcement, news } \\
\text { item. }\end{array}$ \\
\hline $\begin{array}{l}\text { Determinig the meaning of } \\
\text { the word. }\end{array}$ & Descriptive, advertisement. \\
\hline $\begin{array}{l}\text { Determining the coherence } \\
\text { and the cohesion of the text. }\end{array}$ & Hortatory exposition, news item. \\
\hline $\begin{array}{l}\text { Determining the reference of } \\
\text { word. }\end{array}$ & Hortatory exposition, \\
\hline $\begin{array}{l}\text { Determining the specific } \\
\text { information of the text. }\end{array}$ & $\begin{array}{l}\text { Discussion, advertisement, news } \\
\text { item }\end{array}$ \\
\hline $\begin{array}{l}\text { Determining the } \\
\text { communicative purpose of } \\
\text { the text. }\end{array}$ & Advertisement. \\
\hline
\end{tabular}

Some procedures have been done to collect the data for this research. To conduct this research, the researcher collected the data by administering test to get the score of English teachers related to their ability in comprehending factual texts. Then, the researcher distributed the questionnaire.

For the test, the researcher analyzed the data by using simple statistic analysis to get the general picture for the total score of the test. Then, the researcher analyzed the data for each item based in the indicators of the test and made percentage of the result. While for questionnaire, the researcher used descriptive statistic of mean and standard deviation for each item to find out the problems in comprehending factual text and the strategies to solve the problems.

\section{RESULT AND DISCUSSION}

a. Test

After analyzing the data, it is found out that there are so many English teachers failed in the test. Based on the data, seven out of twenty English teachers only passed the standard score of the test. It means that more than half of English teachers of junior high school in Padang Pariaman regency faced some problems in comprehending factual texts. This data also reflect their professional competence related to their ability in mastering learning material which in this case is factual text.

There are eight indicators of professional competence related to comprehend factual texts which were tested in the test. Those indicators are tested for annoucement text, advertisement text, news item text, descriptive text, discussion text, and hortatory exposition text. Based on the result, it can be seen that only $39 \%$ $59 \%$ of English teachers of junior high school were correct answering the questions for each indicators. The result can be seen in the Table 2 .

Table 2. Problems in comprehending factual texts

\begin{tabular}{lll}
\hline No & Indicators & Percentage \\
\hline 1. & Identifying general description of the text. & $58 \%$ \\
\hline 2. & Determining implicit information of the text. & $54 \%$ \\
\hline 3. & Determining explicit information of the text. & $56 \%$ \\
\hline 4. & Determinig the meaning of the word. & $59 \%$ \\
\hline 5. & $\begin{array}{l}\text { Determining the coherence and the cohesion } \\
\text { of the text. }\end{array}$ & $39 \%$ \\
\hline 6. & Determining the reference of word. & $59 \%$ \\
\hline 7. & $\begin{array}{l}\text { Determining the specific information of the } \\
\text { text. }\end{array}$ & $49 \%$ \\
\hline 8. & $\begin{array}{l}\text { Determining the communicative purpose of } \\
\text { the text. }\end{array}$ & $55 \%$ \\
\hline
\end{tabular}

It can be seen that mostly English teachers of Junior high school have problems in determining the coherence and the cohesion of the text. Based on the data, only $39 \%$ of English teachers were able to answer correctly the questions related to this indicator. Next, most of English teachers also found difficulties in determining specific information of the text. It means that English teachers have problems in mastering learning material related to these indicators since more than $50 \%$ of English teachers failed for the questions of these indicators. However more than $50 \%$ of English teachers were correct answering questions for indicators dentifying general description of the text, determining implicit information of the text, determining explicit information of the text, determinig the meaning of the word, determining the reference of word, and determining the communicative purpose of the text.

\section{b. Questionnaire}

The aim of spreading the questionnaire is to collect the data related to the problems of English teachers in comprehending factual texts and their strategies to solve the problems. In this research, the problems of English teachers in comprehending the factual text is divided into two areas, which are linguistics problems and non linguistics problem. Linguistics problems include grammar and vocabulary. While non linguistics problems includes, background knowledge, working memory, connecting ideas, text length, and differentiating text types.

Based on the data, mostly English teachers of junior high school have non linguistics problems. It means that most of English teachers doesnt find any problems with unfamiliar or difficult words and complex grammar. Working memory, connecting ideas, and text length are their major problems in comprehending factual text. They tend to forget what they just read and it takes long time for them to understand the text since they need to read the text again. Furthermore, connecting ideas is not an easy thing to do. When the text became more complex and long, it is difficult for them to connect ideas from each paragraph which make the text is difficult to be comprehended. The strategies they do to solve these problems are various. Based on the result of questionnaire, the English teahers 
prefer to take notes and underline or circle the important information in the text. They also try to concetrate more and decide what to ignore and what to read when it comes to long text. they also believe reading strategy and their background knowledge related to the text types help them alot to comprehend the factual text.

\section{CONCLUSION}

Obtaining professional competence is not easy. Professional competence is the combination of knowledge and skill that should be obtained by English teachers including material, concept and structure. As stated in Government Regulation No. 74 year 2008, professional competence is a competence of teachers to teach the class related to their professional knowledge and skill of a subject matter. Since the demand of education in Indonesia does not only focus on students but also on teachers, every teacher is expected to be able to meet the society needs and to answer the local and global challenges.

\section{ACKNOWLEDGMENTS}

I would like to thank the lecturers of English Department of Faculty of Language and Arts, Universitas Padang, for the guidance, suggestion, and contribution to this article.

\section{REFERENCES}

[1] Anugerahwati., \& Saukah, A. 2010. Professional Competence of English Teachers in Indonesia : a Profile of Exemplary Teacher. Indonesian Journal of English Language Teaching. 6(2). 107-112.

[2] Atmaca, Ç. 2017. English teachers' perspectives about teacher competencies in terms of professional identity. Abant İzzet Baysal Üniversitesi Eğitim Fakültesi Dergisi. 17 (4), 1641-1669

[3] Mulyasa, E. 2009. Standar Kompetensi dan Sertifikasi Guru (Cet. 5). Bandung: PT. Remaja Rosdakarya..

[4] Permendiknas No, 16 Tahun 2007 Tentang Standar Kualifikasi Akademik dan Kompetensi Guru.

[5] Peraturan Pemerintah Republik Indonesia Nomor 19 Tahun 2005 Tentang Standar Nasional Pendidikan.

[6] Peraturan Pemerintah RI Nomor 74 Tahun 2008 tentang Guru.

[7] Puspita, Ariyanti. 2017. Students Difficulties in Comprehending English Reading Text at Second Grade Students of SMAN 2 Metro. University of Lampung. Published Thesis.

[8] Raisha, Siti. 2017. EFL Students' Reading Comprehension Problems Linguistics and Non Linguistics Complexities. English Educational Journal (EEJ).8(3), 308-321
[9] Shehu, Irena. 2015. Reading Comprehension Problems Encountered by Foreign Language Students, Case Study: Albania, Croatia. Academic Journal Interdisciplinary Studies. 4(1), 91-96.

[10] UU RI No. 14 Th. 2005. Guru dan Dosen. Jakarta: Sinar Grafika. 2005.

[11] Wuthisingchai, Sajeerat. 2011.A Survey Study of Reading Comprehension Problems in Academic Texts as Perceived by Mathayom 5 Students in the English Program at Thai Christian School. Published Thesis. 